University of California, Hastings College of the Law UC Hastings Scholarship Repository

Faculty Scholarship

1998

\title{
Truth Commissions and Amnesties in Latin America: The Second Generation
}

Naomi Roht-Arriaza

UC Hastings College of the Law, rohtarri@uchastings.edu

Follow this and additional works at: http://repository.uchastings.edu/faculty_scholarship

Part of the Human Rights Law Commons

\section{Recommended Citation}

Naomi Roht-Arriaza, Truth Commissions and Amnesties in Latin America: The Second Generation, 92 Am. Soc'y Int'l L. Proc. 313 (1998). Available at: http://repository.uchastings.edu/faculty_scholarship/698

This Article is brought to you for free and open access by UC Hastings Scholarship Repository. It has been accepted for inclusion in Faculty Scholarship by an authorized administrator of UC Hastings Scholarship Repository. For more information, please contact marcusc@uchastings.edu. 


\section{Faculty Publications \\ UC Hastings College of the Law Library}

Author: Naomi Roht-Arriaza

Source: $\quad$ American Society of International Law Proceedings

Citation: 92 Am. Soc'y Int'I L. Proc. 313 (1998).

Title: $\quad$ Truth Commissions and Amnesties in Latin America: The Second Generation

Originally published in AMERICAN SOCIETY OF INTERNATIONAL LAW PROCEEDINGS. This article is reprinted with permission from AMERICAN SOCIETY OF INTERNATIONAL LAW PROCEEDINGS and American Society of International Law . 


\section{Transitional Justice: Amnesties, Truth COMMISSIONS AND BEYOND}

The panel was convened at 9:10 a.m., Saturday, April 4, by its Chair, Ellen Lutz, who introduced the panelists: Naomi Roht-Arriaza, University of California, Hastings College of Law; Ruti Teitel, New York Law School; and Heinz Klug, University of Wisconsin Law School.

\section{TRUTH COMMISSIONS AND AMNESTIES IN LATIN AMERICA: THE SECOND GENERATION}

\section{by Naomi Roht-Arriaza**}

Truth commissions as an accountability strategy came to international attention beginning in the 1980s as a result of events in Latin America, particularly in the Southern Cone. Latin America is also one of the first places where conflict occurred over whether amnesties for the military for crimes committed while in power should be respected.

In countries where civilian governments came to power after repressive military regimes or civil wars (or both), they set up highly respected commissions to look into disappearances and murders. Argentina set up the Sábato Commission to investigate disappearances, and tried the heads of the military juntas. But it later enacted de facto amnesty laws, and eventually pardoned all those convicted for their roles in the campaign of domestic government terrorism during the 1970 s known as "the dirty war." In Chile, President Patricio Aylwin set up the Rettig Commission to investigate deaths and disappearances, under a policy of "all the truth and as much justice as possible." Both countries also set up extensive compensation programs. The thought was that justice was unattainable because the military was too powerful and would destabilize democracy, so these measures-truth telling plus compensation, but no legal punishment-were the best that could be achieved.

It seems this conclusion was premature. The Argentine parliament recently repealed the due obedience and punto final laws, which had resulted in de facto amnesty, thus allowing the reopening of many prosecutions. Buenos Aires federal courts are slowly reopening cases, including those involving disappearances and killings at the Naval Academy and by the army, stating that the right to truth and the right to mourn the dead require a full investigation. The head of the armed forces has admitted that they had used unlawful methods; a former officer admitted throwing prisoners into the sea from helicopters.

In Chile too, the issue of judicial action against the perpetrators of human rights abuses, long thought dead or at least dormant, is heating up again. Ex-dictator Augusto Pinochet has been sued for ordering disappearances in a case pending in Chilean courts, and widespread protests greeted him when he took his reserved seat in the Senate. So my first point is that those who posited that truth could substitute for justice, could even in some cases be a better form of justice, are now seeing that even almost twenty years later the thirst for justice is there even after at least a good part of the truth has been officially acknowledged. In both Argentina and Chile, families and survivors want more than to know who was killed-they want to know who killed them, why and where the body is buried. They want to recover the body and be able to bury their loved ones with dignity. And they want an admission of official culpability from the military, even more than individual trials of lower-ranking soldiers. The current activity in the Southern Cone makes the point human rights advocates

'Tufts University, Fletcher School of Law and Diplomacy, Medford, Mass.

"Professor of Law, University of California, Hastings College of Law, San Francisco. 
have been making for years-that truth and justice are complementary. One does not substitute for the other.

A second issue concerns the role of international law in designing accountability measures and in how amnesties have fared in the courts. A number of international lawyers have argued over the years that blanket amnesties for a certain class of crimes: genocide, war crimes, crimes against humanity, torture and disappearances—at the least—are not allowed under international law. Latin America was one of the first testing grounds of this argument, since in many Latin American countries the military passed self-amnesties before giving up power. In others, a blanket amnesty was negotiated formally or informally as the price for the military's relinquishment of control or for an end to civil war. The Inter-American Commission has stated that these amnesties violate the American Convention's provisions on the right to a fair trial, the right to remedy and the obligation to ensure rights in cases involving Argentina, Uruguay, El Salvador and Chile. ${ }^{1}$

On the bright side, it is possible to see some movement away from blanket amnesties in recent years. The best example is Guatemala, where a UN-brokered peace agreement included a provision stating that the government would not impede prosecutions for human rights violations. A year later, the Congress passed an amnesty law. However, exceptions written into the law prohibited amnesty for disappearances, torture and genocide, and required case-by-case determinations as to whether a particular case involving the security forces could be classified as having an objective related to the recent armed conflict in Guatemala and a sufficiently close tie between that objective and the crime to warrant prosecution. Parties to the negotiations have indicated that the amnesty law was designed to avoid conflict with Guatemala's international law obligations (although questions remain about whether it actually does, especially in cases of larger-scale massacres). To date, local courts have not granted amnesty to security forces for human rights abuses-which does not, of course, mean that such crimes are being prosecuted in any meaningful sense.

Latin American domestic courts' treatment of frontal challenges to amnesty laws is less encouraging. As in South Africa, these challenges have been unsuccessful in every Latin American country where they have occurred: Argentina, Chile, El Salvador, Guatemala and Peru. Courts have rejected arguments based on international law in these cases, either on grounds that the legislature is supreme and courts should not interfere with legislative decisions, or because they find the international legal obligation not clear. A number of courts have used Article 6(5) of Protocol II of the Geneva Conventions in support of their refusal to invalidate amnesties. That provision states: "At the end of the hostilities, the authorities in power shall endeavor to grant the broadest possible amnesty to persons who have participated in the armed conflict, or those deprived of their liberty for reasons relating to the armed conflict, whether they are interned or detained." The context, drafting history and subsequent interpretation by the International Committee of the Red Cross (ICRC) all indicate that this provision was never intended to shield violators of international humanitarian law, despite the courts' attempt to use it that way.

It seems that the fragility of the judiciary, and a lack of recent experience with judicial oversight of the constitutionality of government policy, have made it difficult for domestic courts to stand against the political decision of the executive or legislature to enact a blanket amnesty, particularly in the context of peace accords or deals with the military. Another line of cases has been more successful. These take the amnesty as a given but insist on the need

'See Inter-American Commission on Human Rights, Las Hojas Case (El Salvador), Case 10.287, Inter-Am. C.H.R. 88 (1993); Hugo Leonardo et. al. (Uruguay), Case 10.029, Inter-Am. C.H.R. 154 (1993); Alicia Consuela Herrera et al. (Argentina), Case 10.147, Inter-Am. C.H.R. 41 (1993); Garay Hermosilla et.al. (Chile), Case 10.843, Inter-Am. C.H.R. 156 (1997). 
to investigate the facts to see if the amnesty applies. In Chile, for example, the so-called Aylwin doctrine held that courts should investigate disappearance cases, even calling military officers to testify if needed, up to the point at which the court could determine that a crime coming within the terms of the amnesty had been committed. Recent cases in Argentina, Honduras and Guatemala involve courts insisting that they have jurisdiction to investigate, and that only after investigation will it be possible in each individual case to determine whether or not the amnesty applies. ${ }^{2}$ In effect, this transforms a blanket amnesty into a series of case-by-case determinations.

A recent Honduran case involving the abduction and torture of a group of students (who were later released) is illustrative. ${ }^{3}$ The initial decision affirmed the court's investigatory jurisdiction. A subsequent decision affirmed application of the amnesty law, but only after a long and detailed exposition of the acts committed by the military and an expression of outrage by the court over the barbarity of the tactics used. The decision shows both the limits of the case-by-case strategy -in the end, the military walks free-and its potential. In effect, the court becomes a forum for truth telling, making detailed findings of fact and expressing community opprobrium. In a sense, the court becomes a kind of mini-"truth commission" for a specific set of acts. Advocates of trials have always argued that their truth-telling functions are as important as their punishment-related ones: these cases sharply differentiate the two functions and raise interesting questions about whether truth telling by a court, like truth telling by a commission, is enough.

A third trend in court cases also raises questions about the role of the legal process: several cases have been brought in national courts in other jurisdictions. ${ }^{4}$ For example, the Audiencia Nacional, set up by the Spanish Government to hear cases of terrorism, is investigating the deaths of Spanish citizens in Argentina and Chile during the dirty wars. In the Argentine case, the Spanish court has issued international arrest warrants, and requests to Switzerland to freeze the assets of some forty military officers. One officer has been jailed in Spain pending trial. The Argentine Government has refused to cooperate in extraditing the defendants or providing information, and has raised the amnesty as a defense. The Spanish court has responded that an amnesty contrary to both Spanish and international law cannot bind the Spanish courts. Because most of the defendants are unlikely to appear before the court, these proceedings, and similar ones in Italian, Ecuadorian and possibly German courts, act as a kind of analog to the Rule 61 proceedings in the International Criminal Tribunal for the Former Yugoslavia, restricting the mobility of the defendants. The proceedings also raise interesting questions about the criteria a foreign court should use in deciding to ignore a domestic amnesty: Would a decision by Spain to try someone who was granted amnesty through the South African Truth and Reconciliation Commission, for example, be acceptable?

Finally, where we go from here: Where's the "beyond" in our panel title?

First, in many countries in Latin America, one of the crucial unresolved issues is the fate of the disappeared and of children born in captivity. A whole social process has grown up around the finding and exhumation of bodies, their ceremonial reburial, and the collective grieving that accompanies this process. The "right to mourn" is slowly being recognized as

\footnotetext{
${ }^{2}$ For a full description of these cases, see Naomi Roht-Arriaza \& Lauren Gibson, The Developing Jurisprudence on Amnesty, HUM. RTS. Q. (forthcoming Nov. 1998). 1998.

${ }^{3}$ Salazar Mena case, Juzgado de Letras Primero de lo Criminal, Tegucigalpa, Honduras, Jan. 22,

${ }^{4}$ Orden de priscón provisional incondicional de Leopoldo Fortunato Galtieri, Juzgado No. 5, Audiencia Nacional española, Mar. 25, 1997, available at http://www.derechos.org/ nezkor/arg/espana/autogalt.html. See Roht-Arriaza \& Gibson, supra note 2.
} 